\title{
TELEVISUAL SATIRE IN THE AGE OF GLOCALIZATION
}

\section{THE CASE OF ZONDAG MET LUBACH}

Ivo Nieuwenhuis

Radboud University Nijmegen

Department of Dutch Language and Culture

Postbus 9103

6500 HD Nijmegen

The Netherlands

i.nieuwenhuis@let.ru.nl

Abstract: This article analyses the highly popular Dutch satirical TV-show Zondag met Lubach (ZML) from the perspective of 'glocalization.' This places the show both within the global tradition of late-night satire, originating in the United States, and in the local Dutch tradition of satirical TV. A general overview of these traditions is followed by a close reading of one ZML segment, which is then compared to the American show Last Week Tonight with John Oliver. This comparison reveals the dominant influence of the American tradition of performing televisual satire, thus contesting the common assumption in television studies that nationhood still plays a central role in the practice of broadcasting.

Keywords: satire TV, glocalization, Netherlands, news parody, transnationalism, television history

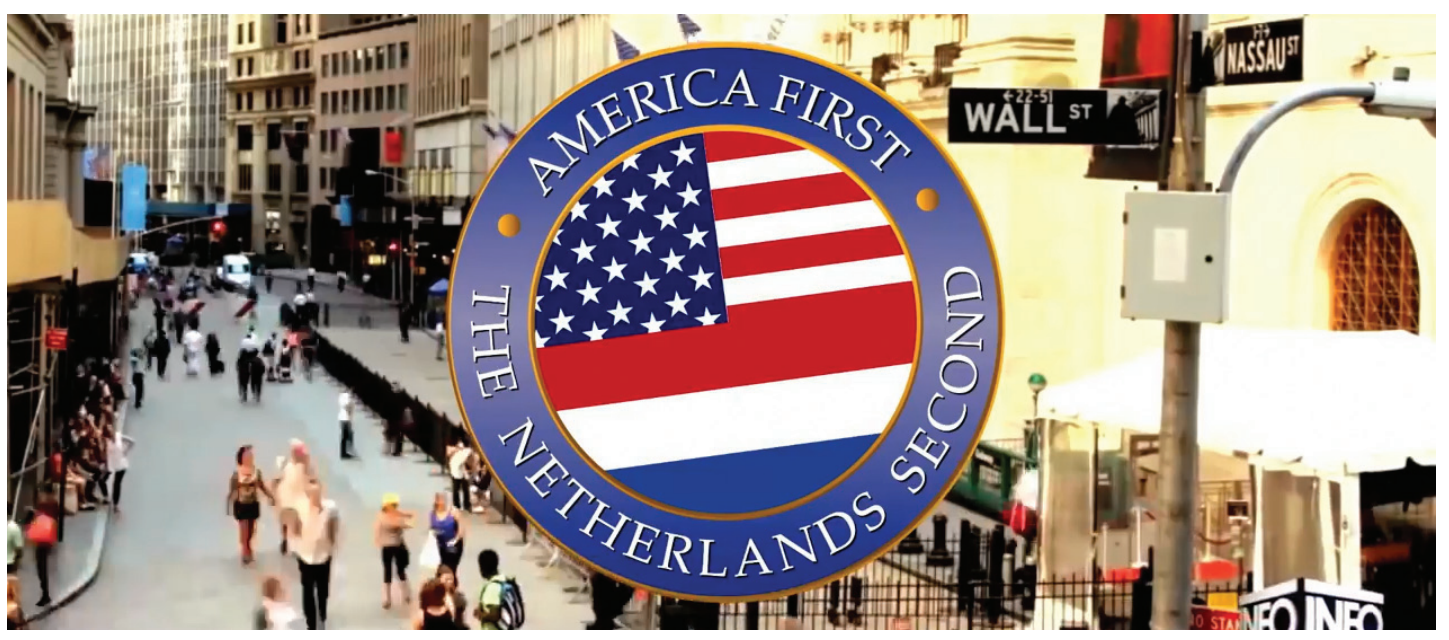

Video 1. The Netherlands welcomes Trump in his own words. Video from Zondag met Lubach, first aired on 22 January 2017. Go to the online version of this article to watch the video. 
Sunday, 22 January 2017 was a memorable day for the Dutch satirical TV-show Zondag met Lubach ('Sunday with Lubach'; hereafter: $Z M L)$. On that date (ZML 6:1), the show, hosted by comedian Arjen Lubach, aired a video that jocularly replied to U.S. President Donald J. Trump's claim that, with the commencement of his presidency just a few days before, it was going to be 'only America first.' The video introduced the Netherlands to Trump, acknowledging his wish that America be 'first,' but requesting, in return, that the Netherlands be made 'second.' This request was supported by a parody of Trump's bloated rhetoric, claiming, among other things, that the Dutch language is 'the best language in Europe. [...] All the other languages failed. Danish...total disaster. German is not even real language. It's fake.' Soon after the video was placed on You Tube, a regular practice for ZML items, it went viral. By February 2018, the original Dutch version of the video had approximately 10.9 million views, and the version with English subtitles over 26 million.

When the 'Netherlands Second' video came out, ZML already had quite respectable ratings, but they went up significantly in the following weeks. The episode of 22 January 2017 had 627,000 viewers, that of 29 January 1.02 million. Of the other eight episodes during this season, five reached over a million viewers, and the other three came close to that number, as well. ${ }^{1}$ Meanwhile, the show also continued to receive positive critical reviews. ${ }^{2}$ Already, in 2016, it had won the Zilveren Nipkowschijf (Silver Nipkow Disk), a prestigious Dutch television award. Last, but not least, ZML was awarded the Gouden Televizier Ring (Golden Televizier Ring), an important public award, in October 2017.

In this light, it may come as a surprise that, when Lubach started his show in November 2014, its prospects were not necessarily good. Attempts to transpose the highly popular U.S. format of late night satire to Dutch television had been made before, but none of them were very successful. De Nieuwste Show (2007-2008), a Dutch adaptation of The Daily Show with Jon Stewart, co-hosted by Lubach, ran for only one season. ${ }^{3}$ Comedy Central News (2007-2008), produced by the Dutch comedy collective Boom Chicago and broadcast by Comedy Central Netherlands, completed 83 fifteen-minute episodes, but was still cancelled after two seasons and never reached a large audience. ${ }^{4}$ The same was true for Panache (2012-2013), another Daily Show adaptation, hosted by comedian Jan Jaap van der Wal. Based on these failed attempts, it was assumed for a long time that the 'Daily Show formula' simply was not fit for Dutch television.

But ZML turned out to have a better fate. The show received positive reviews from the outset. ${ }^{5}$ By 2018 , it had become more popular than ever. In this article, I take this moment of success in January 2017 as the starting point for an assessment of the show's formal properties and cultural significance. In particular, I am interested in how ZML relates to the current transnational television landscape. Recent scholarship claims that this landscape is characterized by a strong movement towards 'glocalization,' a situation in which internationally distributed TV formats like Big Brother and Pop Idol more and more set the scene, but only because these formats have the quality of being easily adaptable to local cultural contexts. ${ }^{6}$ I will address this question of glocalization and its impact on ZML by tracing both the global and local traditions to which it can be said to belong. For the global aspect, I will focus on the originally American genre of late-night satire. For the local aspect, I will focus on the very rich domestic tradition of satire TV in the Netherlands. After having sketched these two contexts in broad lines, I will offer a close analysis of the stylistic and thematic characteristics of ZML, which I will then confront with both the American and domestic tradition of televised satire. This confrontation will show that ZML's local embeddedness is rather weak, thus contesting the common assumption in television studies that nationhood still forms a central notion in the practice of broadcasting. ${ }^{7}$

\footnotetext{
1 For a complete overview, see the entry on Zondag met Lubach on Wikipedia.nl.

2 See, for example, Haro Kraak, 'Waar moderne dominee Arjen Lubach preekt, daar volgen zijn kijkers', in De Volkskrant, 14 October 2017,

published online as 'Kennelijk is de tijd rijp voor dominee Lubach met geestige tirades die ook echt ergens over gaan'.

3 'De Nieuwste Show,' Wikipedia.nl.

4 'Comedy Central News,' Wikipedia.nl.

5 See, for example, Hans Beerekamp, 'Na drie keer staat Lubach als een huis', in NRC Handelsblad, 24 November 2014.

6 Jean K. Chalaby, 'The Making of an Entertainment Revolution: How the TV Format Trade Became a Global Industry,' European Journal of Communication, 26, 4, 2011, 293-309; Albert Moran, Understanding the Global TV Format, Intellect, 2006; and Silvio Waisbord, 'McTV:

Understanding the Global Popularity of Television Formats,' Television \& New Media, 5, 4, 2004, 359-383.

7 Cf. Chalaby, 'An Entertainment Revolution,' p. 306, and Waisbord, 'McTV,' p. 360 and 367.
} 


\section{Satirizing the News}

Late night satire, as it can be found on U.S. television today, is the product of two distinct generic traditions. The first is that of the late-night talk show. This TV genre dates back to the 1940s. Its main characteristic is the central role of the show's host, for whom the show is often named - as in The Ed Sullivan Show (1948-1971) and Late Night with David Letterman (1982-1993) - and who starts the show with an opening monologue. Other recurring elements are interviews with celebrities, live musical performances, and audience participation. ${ }^{8}$ The overall intent of a late-night talk show is to offer light entertainment. The shows are broadcast on a weekly or daily basis. This gives them the opportunity to quickly respond to topical events. Up till this day, the genre has been highly popular in the United States and is a regular feature on most television networks, filling the last segment of their prime-time slots, usually somewhere between 22:00 and midnight.

Shows like The Daily show with Trevor Noah (Comedy Central) and Last Week Tonight with John Oliver (HBO) can be considered part of this vivid tradition of late-night talk shows, but they differ from it, as well. Whereas the typical late-night talk show limits itself to a light-hearted discussion of newsworthy events, with a focus on human interest, these shows take a more hard-boiled approach. They intend to seriously question the political situation as it is. Hosts, such as Trevor Noah and his famous predecessor, Jon Stewart, present themselves as the watchdogs of democracy and public debate, unafraid to deliver an inconvenient truth when they deem it necessary. ${ }^{9}$ This makes their shows potentially much more provocative than the average late-night talk show. The latter mainly tries to please the audience and aims to reach the largest audience possible, whereas Stewart, Noah and Oliver deliberately limit their outreach by uttering statements that will most certainly displease part of the American public.

By doing so, The Daily Show and its compatriots fit within the more general shift from broadcasting to narrowcasting that U.S. television underwent in the 1980 s. ${ }^{10}$ From the early years of television until that time, broadcasting in the United States was dominated by a small group of big commercial networks (CBS, NBC, and ABC) which all tried to get the largest share of the TV market. To reach this aim, their programmes needed to attract as many viewers as possible. This generally led to a conservative programming strategy, in which anything that could be deemed controversial either politically, socially, or morally - was avoided. The classic late-night talk show neatly fit within this strategy, as did the average sitcom. ${ }^{11}$ The 1980 s saw the birth of subscription-based cable television, which led to a multiplication of channels, thus creating much more room for dissenting tastes and opinions. The television market was now no longer dominated by three or four big networks, but by a wide variety of smaller channels, who were catering to the needs of very specific audiences. Cable television facilitated the emergence of channels devoted to science, history, cooking, and the news. As a result, it was no longer necessary for a TV show to please as many people as possible to be commercially viable. On the contrary, the new niche market demanded a certain outspokenness of a channel to secure attractiveness to its viewers. It should not come as a surprise, then, that, ever since the rise of cable television, provocative broadcasting has been thriving in the U.S.

On The Daily Show and other shows following the same format, these provocations mainly take the form of ridicule. This brings to the fore the second generic tradition significant to the development of late-night satire, that of news parody. This genre has a long history. It can be traced back to the eighteenth century, in which some of the early journalists specialized in satirical magazines which parodied the conventions of the official news media. ${ }^{12}$ On television,

8 Rodney A. Buxton, 'The Late-Night Talk Show: Humor in Fringe Television,' Southern Speech Communication Journal, 52, 4, 1987, $377-389$.

9 Cf. Jonathan Gray, Jeffrey P. Jones, and Ethan Thompson, 'The State of Satire, the Satire of State,' in idem (eds.), Satire TV: Politics and Comedy in the Post-Network Era, New York University Press, 2009, p. 3-36.

10 This shift is discussed in more detail in: Albert Moran, 'Configurations of the New Television Landscape,' in Janet Wasko (ed.), A Companion to Television, Blackwell, 2005, p. 291-307; and Gray et al., 'The State of Satire,' p. 19-28.

11 Cf. Gray et al., 'The State of Satire,' p. 14.

12 On these eighteenth-century news parodies, see Ivo Nieuwenhuis, 'Enlightenment Subverted: Parody as Social Criticism in Pieter van Woensel's Lantaar,' in: Marijke Meijer Drees and Sonja de Leeuw, eds, The Power of Satire, John Benjamins, 2015, p. $217-232$. 
the genre dates back to the 1960s, when BBC Television broadcasted That was the week that was (1962-1963), a weekly show commenting on the news in a derisive manner.

In news parodies, irreverent jokes about politicians and other important public figures are combined with a critical take on how the news is covered in the official, non-satirical press. This is done by parodying the style and conventions of these 'serious' news media. The Daily Show does this, for example, by working with fictional reporters, who pretend to be at an important news location, delivering live coverage. This segment of the show mocks the sensationalism of many regular news shows. ${ }^{13}$ Another good example is The Colbert Report (2005-2014), in which comedian Stephen Colbert parodied a right-wing political pundit, the type of talk show host that is regularly found on channels like FOX News. This parody intended to show the narrowmindedness of these pundits and prove their negative influence on public debate. ${ }^{14}$

News parody has become a popular genre worldwide. ${ }^{15}$ This popularity seems to be at least partly due to the great successes of Jon Stewart and Stephen Colbert in the 2000s with their respective shows. These shows were known across the globe and inspired the development of local variants. ZML can be considered as such a variant, as can, for example, the also successful German Neo Magazin Royale, hosted by comedian Jan Böhmermann. That show is broadcast by the German channel ZDF. It started in October 2013 and reached international fame in March 2016 when an ironic segment of the show led to Böhmermann being prosecuted for slandering by the Turkish president Recep Tayyip Erdoğan. ${ }^{16}$

In the wake of the growing popularity of news parody in the United States and other countries from the late 1990s onwards, many studies were conducted on this genre. Especially within the field of political communication, a substantial body of scholarly work arose, in which the effects of news parody on the public sphere and the overall functioning of contemporary democratic societies formed the main issue. Key publications include the essay collections Satire TV (2009), edited by Jonathan Gray, Jeffrey P. Jones, and Ethan Thompson, and The Stewart/ Colbert Effect (2011), edited by Amarnath Amarasingam, and the monographs of Jones (Entertaining Politics, 2005; revised edition in 2010) and Geoffrey Baym (From Cronkite to Colbert: The Evolution of Broadcast News, 2010). ${ }^{17}$ The majority of these studies present news parody, and satire TV more generally, as a positive force, a means to make the public sphere more accessible and, eventually, more democratic, especially for younger generations. ${ }^{18}$ With this claim, the authors try to counter the common assumption that shows such as The Daily Show are an expression of political cynicism, and thus harmful to liberal democracies. ${ }^{19}$

The international victory march of news parody can be directly related to the earlier mentioned trend in television culture worldwide towards glocalization. The spectacular rise of the TV-format business after 2000 is usually seen as the main proof of this trend. ${ }^{20}$ The term format here refers to 'a show that can generate a distinctive narrative and is licensed outside its country of origin in order to be adapted to local audiences.' It is 'a vehicle which enables an idea

13 For a more profound discussion of The Daily Show as news parody, see Amber Day, 'And Now...the News? Mimesis and the Real in The Daily Show,' in: Jonathan Gray, Jeffrey P. Jones, and Ethan Thompson, eds, Satire TV: Politics and Comedy in the Post-Network Era, New York University Press, 2009, p. 85-103; and Joanne Morreale, 'Jon Stewart and The Daily Show: I Thought You Were Going to Be Funny', in idem, p. 104-123.

14 On The Colbert Report as news parody, see Geoffrey Baym, 'Stephen Colbert's Parody of the Postmodern', in: Jonathan Gray, Jeffrey P. Jones, and Ethan Thompson, eds, Satire TV: Politics and Comedy in the Post-Network Era, New York University Press, 2009, p. $124-144$.

15 For a discussion of the global dimensions of news parody, see the special issue of Popular Communication: The International Journal of Media and Culture, 10, 1-2, 2011, edited by Geoffrey Baym and Jeffry P. Jones.

16 On this 'Böhmermann affair', see Wikpedia.en.

17 Gray et al., Satire TV; Amarnath Amarasingam, ed, The Stewart/Colbert Effect: Essays on the Real Impacts of Fake News, Jefferson, McFarland, 2011; Jeffrey P. Jones, Entertaining Politics: Satiric Television and Political Engagement, Rowman \& Littlefield, 2010; Geoffrey Baym, From Cronkite to Colbert: The Evolution of Broadcast News, Paradigm Publishers, 2010.

18 The issue of accessibility forms the particular focus of Mark Boukes, 'Spicing Up Politics: How Soft News and Infotainment Form Political Attitudes,' doctoral dissertation, University of Amsterdam, 2015.

19 Cf. Gray et al., Satire TV, p. 7.

20 Chalaby, 'An Entertainment Revolution', p. 298. 
to cross boundaries, cultures, and so on, and to be localized in every place where it stops. ${ }^{21}$ Game shows and reality TV are the most popular occurrences of this phenomenon, but soap operas and sitcoms are good examples, as well. ${ }^{22}$ Following this line of argument, the widespread occurrence of news parodies outside the U.S. can also be seen as part of the international TV-format industry. Many of these parodies follow the basic 'Daily Show formula' of a host sitting behind a desk, poking fun at politicians and recent political events, and mocking the coverage of these events by serious media. ${ }^{23}$ At the same time, they are significantly fashioned by the local political and cultural context in which they appear, which brings to the fore its own particular power dynamics and institutional limitations. This local context determines, for example, how much room there is for challenging authoritative discourses and what styles of humour are deemed appropriate for the local viewing audience. When assessing ZML's position within television culture, we should thus also take into account its local predecessors and the national political landscape to which it belongs.

\section{Dutch Satire TV from Zo Is Het to De Kwis}

The institutional logic of television in the Netherlands differs strongly from that of the United States. Commercial networks only entered the market in the late 1980s, as was the case in most European countries. Until then, public television was the sole player in the field. In 2016, it still had a market share of $35.1 \% .{ }^{24}$ What makes the Dutch public broadcasting system unique is its separation between channels and broadcasting societies. Since 1988, there have been three public TV channels. The total amount of broadcasting hours available on these three channels is divided among eight broadcasting societies..$^{25}$ They each get their share, which is largely based on their membership count. Together, they are supposed to form a faithful reflection of the Dutch public. ${ }^{26}$ This set-up dates back to the early twentieth century, when Dutch society was dominated by a system known as pillarization. ${ }^{27}$ Within pillarization, social life was organized along ideological and confessional lines. Each confession or ideology had its own schools, newspapers, and even grocery stores. When radio was introduced in the 1920s, the influence of this system was at its height, making it a logical choice with which to organize radio broadcasting along the same lines. Protestant, Catholic and social-democratic broadcasting societies were founded, of which ordinary citizens became paid members on a large scale, thus expressing their loyalty towards a particular pillar. Despite the disappearance of pillarization as an organising principle in Dutch society after the 1960s, these societies are still in place and, altogether, count 3.5 million members. ${ }^{28}$ They shape the organisation of Dutch public television until this very day.

This structuring of public broadcasting along ideological lines had a significant impact on the possibilities for performing televisual satire in the Netherlands. Unlike the big commercial networks in the United States, the Dutch broadcasting societies did not need to please the largest audience possible with their programmes, although they were all keen on

21 Ibid., p. 296 and 295, resp.

22 Ibid., p. 303.

23 Several articles in the special issue of Popular Communication on news parody (see note 15) exemplify this use of the 'Daily Show formula' outside the U.S.

24 'Jaarpersbericht Kijkcijfers 2016', Stichting Kijkonderzoek 7 January 2017.

25 There used to be many more. Until 2016, as many as 21 organizations were represented on Dutch public television.

26 Due to decreasing membership counts, this system has been revised recently, making it less dependent on these counts. However, in 2014 , all broadcasting societies, together, counted 3.5 million members out of a national population of 16.9 million, which is still a significant number. (Source: Commissariaat voor de Media).

27 A good introduction to pillarization forms is: Arend Lijphart, The Politics of Accommodation: Pluralism and Democracy in the Netherlands, University of California Press, 1975.

28 In 2016, many of them merged, including the Protestant (NCRV) and Catholic (KRO) societies, thus decreasing the impact of the old social pillars on the way the system is organised. Nevertheless, the underlying idea of dividing the total amount of air time on Dutch public television among multiple associations, all of whom represent part of the Dutch population, is still largely intact. 
getting good ratings. As a result, their programming strategy was, from the outset, aimed at appealing to the audience by being outspoken, rather than by playing it safe. ${ }^{29}$ The Dutch broadcasting system thus shows a striking resemblances to the niche market that emerged in the U.S. in the 1980s with the introduction of cable television. In both cases, there is ample room for more provocative types of broadcasting, such as satire; however, in the Netherlands, this type of show was able to develop at a much earlier stage.

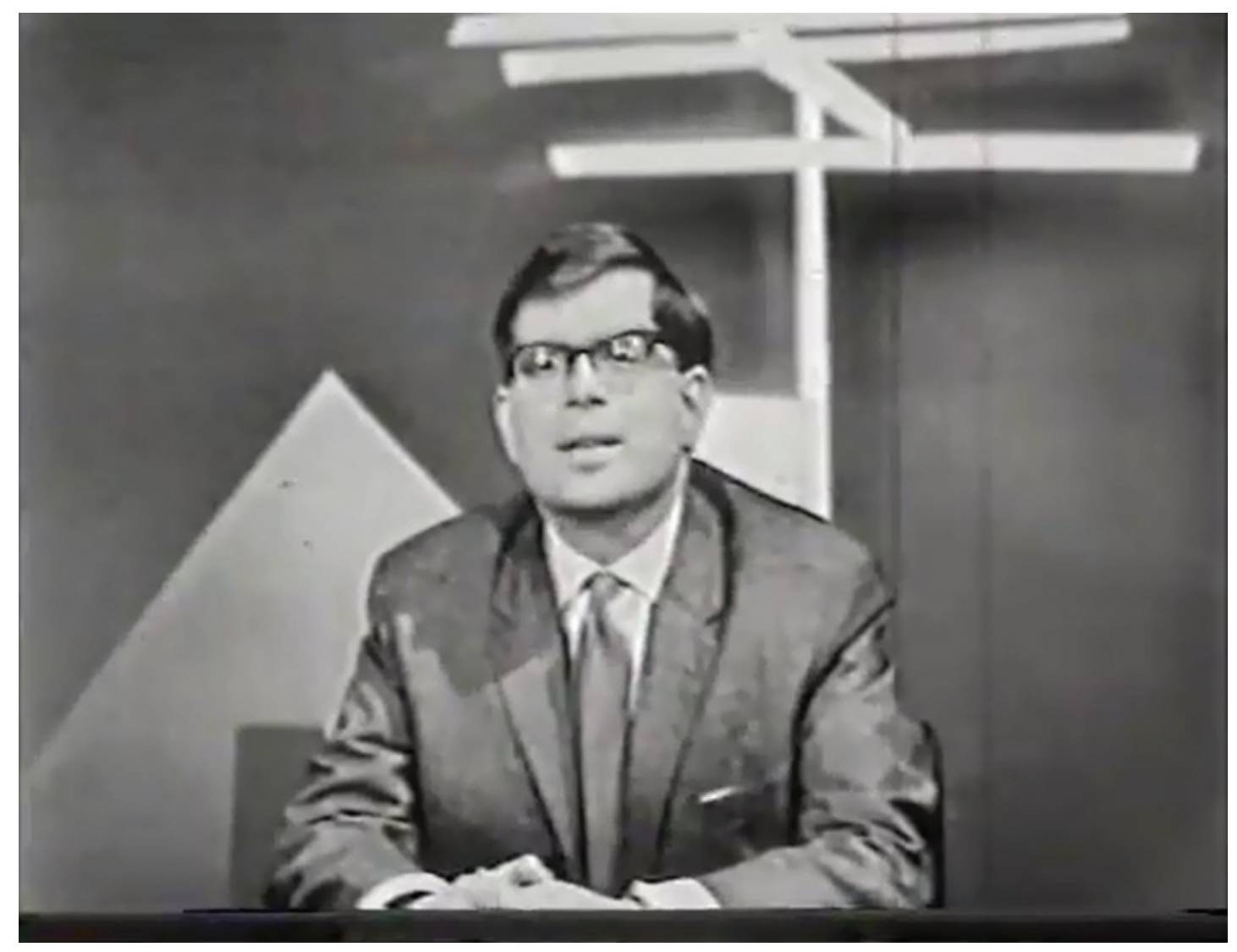

Video 2. Provocative sketch from the Dutch satirical show Zo is het toevallig ook nog eens een keer, mockingly depicting television as a new form of religion, aired on 4 January 1964. Go to the online version of this article to watch the video.

The history of Dutch satire TV began in 1963 with an adaptation of the aforementioned BBC show That was the week that was. This shows that the tradition of televisual satire has been transnational from the outset. ${ }^{30}$ Broadcast by the social-democratic broadcasting society VARA, Zo is het toevallig ook nog eens een keer (1963-1966) intended to criticize political and social authorities in the best progressive tradition. Today, the show is mainly remembered for one highly provocative sketch. In this sketch, 'Beeldreligie' (in season 1, episode 3, 4 January 1964), the new habit of many Dutch people of spending the entire evening in front of their TV screen is satirized. This habit is presented as a new religion, the religion of the Screen. One of the regular contributors to the show, Peter Lohr, plays a TV evangelist, who is preaching about this new religion, thereby parodying the suave tone full of biblical metaphors so typical for evangelists. Although the Christian faith was certainly not the main target of this sketch, it was still

29 Cf. Sonja de Leeuw, 'Televisie verbindt en verdeelt, 1960-1985,' in: Bert Hogenkamp, Sonja de Leeuw, and Huub Wijfjes, eds, Een eeuw beeld en geluid: Cultuurgeschiedenis van radio en televisie in Nederland, Nederlands Instituut voor Beeld en Geluid, 2012, p. $148-187$.

30 On the fundamental transnationalism of television more generally, see: Andreas Fickers and Catherine Johnson, eds, Transnational Television History: A Comparative Approach, Taylor and Francis, 2013. 
considered as blasphemous by many viewers and led to threatening letters directed at the creators of Zo is het. ${ }^{31}$ Ultimately, the show was cancelled after three seasons, basically for being too provocative. ${ }^{32}$

But more satire TV was soon to follow, thanks mainly to the VPRO, arguably the most progressive player within the Dutch broadcasting system in those years. This society originally represented the pillar of liberal Protestantism, but, from the late 1960s onwards, it started to posit itself more and more as the ultimate free spirit of Dutch television. The VPRO was responsible for the first broadcasting of (female) nudity in the Netherlands in 1969 and offered ample room for the televisual experiments of conceptual artist Wim T. Schippers. ${ }^{33}$ Satire formed an essential part of its programming strategy. The main figures responsible for carrying out this strategy were Kees van Kooten and Wim de Bie.

These two men, often simply referred to as Koot \& Bie, were the leading satirists of Dutch television for over three decades. Between 1972 and 1998, they built up an impressive oeuvre of satirical shows. Their main innovation was the introduction of what in Dutch is called a typetje, a fictional character that is supposed to parody a general type of person that every individual viewer could recognize from his or her personal life. Koot \& Bie were very good at those kinds of parodies. Recurring characters in their shows, such as de vieze man (the dirty guy) and de Duitse leraar (the German teacher), became household names among the Dutch audience. Through short sketches starring these characters, all written and played by Van Kooten and De Bie themselves, Dutch politics and society were satirized. ${ }^{34}$

Performing satire through typetjes became a tradition, in and of itself, and continued to exist after Koot \& Bie quit making television. In the early 2000s, a comparable technique was applied in the VARA show Kopspijkers, which ended its weekly broadcast with a panel of fictional characters parodying public figures, who would discuss the news of that week. The two main creators of these characters, Paul Groot and Owen Schumacher, started their own satirical show for the broadcasting society AVRO in 2004. This show, Koefnoen, resembled the older work of Koot \& Bie even more. Each episode consisted of a series of sketches starring recognizable characters from everyday life, through which a general comment on current affairs was delivered. After fifteen seasons, this show was cancelled in 2016.

Many more satirical shows have been broadcasted in the Netherlands over the years. Some lasted for only one season, while others were present in the Dutch TV landscape for many years. Especially popular is the format whereby several comedians are sitting behind a desk, making jokes about the news. A quiz element is sometimes added to this, as in Dit was het nieuws (TROS/RTL, 1996-present) and De Kwis (VARA, 2013-present), the former being an adaptation of BBC's Have I Got News For You? Most shows are scheduled on Saturday evening between 20:00 and 22:00 - i.e., during prime time - making satire a staple of Dutch television.

The room for criticizing authorities always seems to have been large within Dutch satire TV, although the case of 'Beeldreligie' shows that, in the early days, religion was still a taboo subject. We can also trace a steady flow of satirical television through the course of the years. Still, over the last fifteen years or so, the genre has blossomed more than ever before. This situation shows a striking parallel with that in the United States, where satire TV also has been especially thriving in the post-9/11 context. ${ }^{35}$ In both cases, this efflorescence of satire on television might be connected to the heightened political tensions present in society since the early 2000 s.

31 More on this sketch and its consequences in: $\mathrm{H}$. Daudt and B. Sijes, Beeldreligie: een kritische beschouwing naar aanleiding van reacties op de derde uitzending van 'Zo is het, Polak \& Van Gennep, 1966.

32 De Leeuw, 'Televisie verbindt,' p. 152.

33 lbid., p. 174-178.

34 Despite the canonical status of Koot \& Bie in Dutch television history, no comprehensive study of their oeuvre has yet been made. An insightful overview of their careers can be found in a documentary by Coen Verbraak, Van Kooten en De Bie sloegen weer toe, Hilversum: VPRO, 2012, DVD. A first attempt to analyse their work from a scholarly perspective can be found in: Roel van den Oever, 'Carla en Frank van der Putten, moeder en zoon: Een narratologische analyse van de Van Kooten en De Bie filmpjes,' Tijdschrift voor Genderstudies, $16,3,2013,44-53$.

35 Cf. Gray et al., Satire TV; Amarasingam, 'The Stewart/Colbert Effect'; and Jones, Entertaining Politics. 
I. Nieuwenhuis, Televisual Satire in the Age of Glocalization

\section{Funny Bits, Serious Argument}

Since November 2014, ZML has been one of the most recent products of the Dutch satirical tradition. To date, seventy episodes of the show have been produced. ${ }^{36}$ Each episode is circa thirty minutes in length. The lion's share of this time consists of Arjen Lubach sitting behind his desk, delivering monologues about current affairs. ${ }^{37}$ These monologues contain a mixture of jokes, ironic statements, and serious criticism. They are visually supported by various pictures related to the topic at stake, which appear on the left side of the screen throughout the monologue, and by short excerpts of existing news footage, usually illustrative quotes from experts or politicians. There is also aural support in the form of short, funny tunes, activated by Lubach himself through an operating panel that lies on his desk. The monologues vary in length between two and eighteen minutes. There is always one main story, in which Lubach discusses a topic that he finds urgent and on which he usually has a strong opinion. ${ }^{38}$

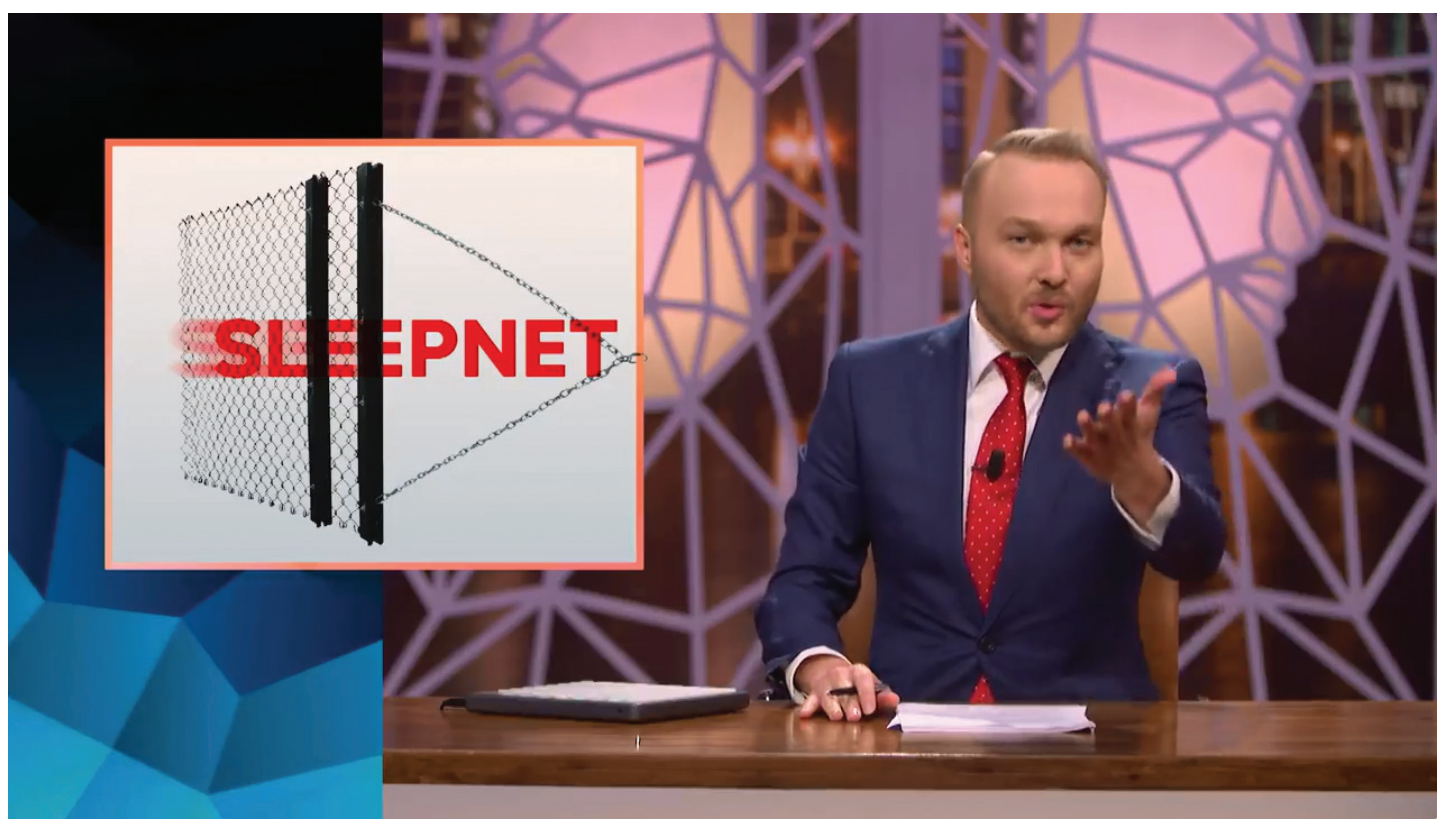

Video 3. Lubach criticizes the 'sleepwet,' a new Dutch secret services law, in the main story of season 7, episode 4, aired on 1 October 2017. Go to the online version of this article to watch the video.

As an example, we can take the main story of season 7, episode 4, which first aired on 1 October $2017 .{ }^{39}$ The topic of this story ('Sleepwet') was a new law that significantly extended the rights of the Dutch secret services to collect personal online data of its citizens. ${ }^{40}$ This law had been the topic of several news stories in the weeks before, following

36 All episodes are available online. They can be viewed on the official ZML website. There have been eight seasons of the show thus far, usually one in the spring and one in the fall of each year. Since season 5 , the standard number of episodes produced per season is ten.

37 Next to monologues, ZML also contains short videos, of which the 'Netherlands second' item discussed in the introduction forms a good example. In the first season, there were also interviews with celebrities. Beginning in season 4, ZML has included fictional reporters in its show.

38 This main story became more important over the course of the seasons, due to the disappearance of the interviews with celebrities (see previous note). Beginning in season 5 , the main story has also lent the respective episode its title.

39 For the complete episode, see the official ZML website.

40 The official name of this law is the Wet op de inlichtingen- en veiligheidsdiensten (Wiv). Further see 'Nieuwe Wet op de inlichtingen- en veiligheidsdiensten (Wiv)', Rijksoverheid. 
I. Nieuwenhuis, Televisual Satire in the Age of Glocalization

the initiative of some students to propose a referendum on it. ${ }^{41}$ They argued that the law violated Dutch citizens' rights to privacy and thus should be amended..$^{42}$ Lubach agreed with them.

When closely analysing this monologue, three elements stand out. First, a large number of jokes are made. The whole segment, which is about 13 minutes in length, contains no less than 24 separate jokes, varying from an ironic response to a statement made about the new law by a member of the Dutch parliament to a comical re-enactment of how the Dutch secret services conducted their investigations in the past. These jokes are neatly spread out over the item. As a result, viewers never have to wait more than thirty seconds before something funny happens. The high joke density of the item also causes it to evoke an overall jolly mood.

This jolliness is somewhat contradicted by the second characteristic element of the monologue, namely that it discusses a serious matter and tries to make a serious point about it. The item follows a clear argumentative logic. Lubach first explains the new law, in short, then systematically lists a total of five criticisms against it, which are followed by a possible objection to his critique, which he, in turn, refutes. He thereby consequently supports his points by referring to serious news sources or official public bodies. Rationality thus typifies this monologue, not only structurally, but also stylistically. Lubach puts factual reasoning upfront.

This rational approach also adds to the third element that catches the eye: the call to action with which the monologue concludes. The viewers of ZML are urged to sign the petition for a referendum on the new law. The webpage they have to go to to do so is visible on the screen. This call turned out to be successful. Soon after the episode aired, the minimum number of 300,000 signatures needed for the petition to qualify for official treatment by the government was reached. It is generally assumed that this would not have happened if Lubach had not promoted the petition on his show. ${ }^{43}$ Apparently, the large number of jokes made during the monologue did not prevent viewers from taking its argument seriously and answering Lubach's call to action.

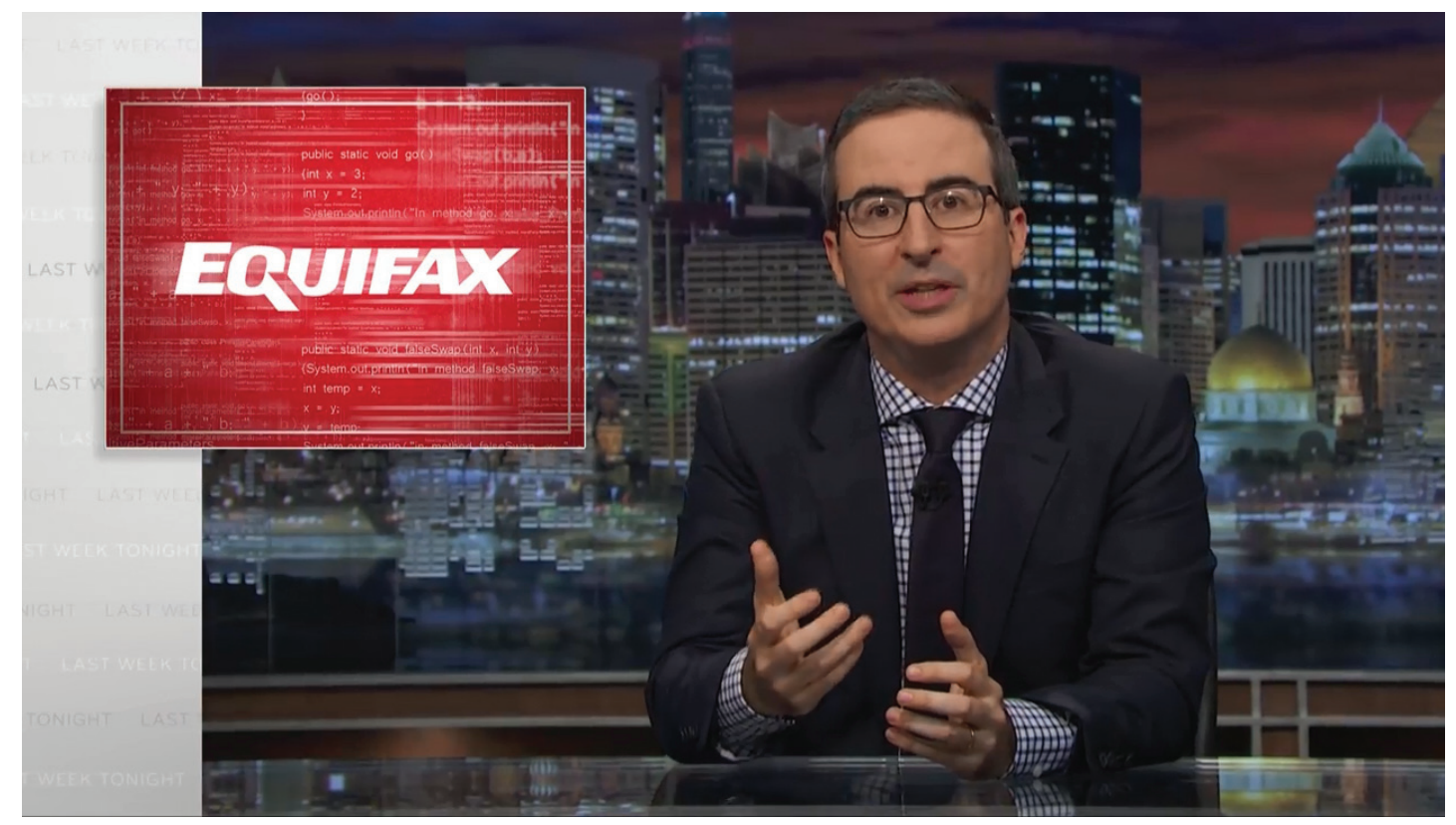

Video 4. Main story of Last Week Tonight with John Oliver, season 4, episode 27, aired on 15 October 2017. Go to the online version of this article to watch the video.

41 See, for example, Huib Modderkolk, 'Een referendum over privacy dient zich aan; moeten we dat wel willen?', De Volkskrant, 21 September 2017; and Luna van der Waarde, 'Help, onze privacy gaat eraan. Sleepwet is sneller van kracht dan we denken', HP/De Tijd, 29 September 2017. 42 Further, see Sleepwet Referendum.

43 Liza van Lonkhuyzen, 'Het 'Sleepwetreferendum' komt er zo goed als zeker, met dank aan Arjen Lubach', NRC Handelsblad, 10 October 2017. 
There is one American late-night show, in particular, to which this sophisticated methodology - a high joke density, combined with rational arguing and an explicit call to action - bears striking resemblance. This is Last Week Tonight with John Oliver. In this show, as well, the lion's share of the thirty-minute broadcast consists of host Oliver sitting behind his desk, delivering monologues. These monologues contain a large number of jokes, but also try to make a serious point, and they do so through factual reasoning, regularly referring to known experts on the topic at stake. There is also often a call to action included. As an example, we can take the main story of season 4, episode 27 (October 15, 2017), which was devoted to the recent discovery of serious security breaches at three major American credit reporting agencies: Equifax, Experian, and TransUnion. In this item, Oliver argues that these agencies cannot be trusted with personal data and encourages his viewers to 'freeze' their credit reports at these agencies. This passionate plea is interspersed with jokes along the lines of: 'Equifax: the company whose name sounds like a theatrical production in which Daniel Radcliffe plays a horse that fucks a fax machine.'

On the weekend that ZML's first episode aired, various local and national newspapers in the Netherlands published articles about this new satirical show. A recurring element in these articles was the mentioning of the fact that, to prepare for his show, Lubach and his team visited the sets of some U.S. late-night satirical shows, including Last Week Tonight. ${ }^{44}$ After closer inspection, we have to conclude that this visit was indeed quite inspirational, up to the point that ZML and Last Week Tonight nearly look like identical twins. Both shows are broadcasted weekly on Sunday evening. They discuss current affairs, mainly through monologues delivered by their respective hosts, two college-educated white males of roughly the same age. ${ }^{45}$ These monologues combine a steady flow of comical remarks with a clear and rational style of arguing, aimed at persuading the audience through reason.

The striking similarity between ZML and Last Week Tonight seems to contradict the idea of glocalization as it is commonly understood. ${ }^{46}$ Apart from the topics discussed, there are no significant differences between the two shows, despite the fact that one is produced for a Dutch audience and broadcast on Dutch public television, whereas the other is predominantly aimed at American viewers. There are barely any signs of local adaptation visible. Admittedly, some minor differences can be recognized. They mainly have to do with the kinds of jokes that are told and the way in which they are told. Lubach makes much use of impersonations. For example, when he is referring to a statement by a Dutch member of parliament on the new secret services law, he parodies the voice of the said politician. He also performs short fictional dialogues in which he impersonates both characters alternately. We do not find this type of roleplaying in Last Week Tonight. Oliver deploys various tones of voice, ranging from deadpan irony to furious anger, but they all belong to his regular persona. We could consider this as a sign of Lubach's indebtedness to the Dutch tradition of performing satire through fictional characters, vis-à-vis the less-theatrical Anglo-Saxon tradition of pure wittiness embodied by Oliver, but we have to concede that this is a subtle 'localization,' at best.

\section{Conclusion}

Returning to the central question of this article - how does ZML relate to the current transnational television landscape? - the answer is: different than we would expect. Despite the strong domestic tradition of satire TV, the 'Dutchness' of ZML is mostly limited to its target audience being Dutch-speaking and familiar with the Dutch news flows to which the show refers. Following the paradigm of glocalization, we would expect local cultural and televisual

44 Helen Albada, 'Arjen Lubach waagt zich aan nieuwsshow,' BN/De Stem, 8 November 2014; Vincent Smits, '”Zelfs over MH17 kun je een grap maken"', AD/Rotterdams Dagblad, 8 November 2014.

45 Lubach was born on 22 October 1979, Oliver on 23 April 1977. Lubach majored in Swedish and philosophy at the University of Groningen. Oliver holds a degree in English from Christ's College, Cambridge University (UK).

46 See note 6. 
traditions to have a much stronger impact on the show, which is, except for a few minor differences, completely modelled after the successful U.S. late-night show Last Week Tonight with John Oliver. This is all the more remarkable when we bring to mind that earlier attempts to import the American late-night satire format to Dutch TV failed.

Why does the glocalization theory not apply here? One explanation may be that the youngest generation of Dutch television viewers is, much more than the generations before it, embedded in the American tradition of satire TV. Although the majority of these American shows have never been broadcasted on Dutch television, large parts of them are easily available through channels such as You Tube. The Internet is becoming, more and more, the dominant medium through which television is consumed in the Netherlands, especially for people below the age of $35 .{ }^{47}$ The latter form a significant portion of Lubach's target audience. ${ }^{48}$ They are the pioneers of what we could call the 'post-linear' moment of television, in which national televisual traditions presumably play a much smaller role than they used to. This situation might even explain why earlier attempts at Dutch late- night satire failed, as the general shift from linear TV-watching to watching online and on-demand is only a very recent one, making the viewer potential for a barely adapted American TV format in the Netherlands today probably much higher than it was only five years ago.

There is obviously much more research needed before more substantial conclusions can be reached on this matter. With this article, I hope to have shown the necessity of actually doing this research. Like its famous Dutch predecessors, Koot \& Bie and Kopspijkers, ZML is not only a popular TV-show, but also an active player in public debates, whose impact on politics can sometimes be very concrete, as with the successful call to action regarding the secret services law referendum. Understanding how satirical shows such as these function within the shifting dynamics of the transnational television landscape will eventually lead to a better understanding of satire TV and its impact on society, at large.

\section{Biography}

Ivo Nieuwenhuis lectures in early-modern Dutch literature and literary theory at Radboud University, Nijmegen (the Netherlands). His research focuses on the history of satire and related genres in the Netherlands, and on the politics of humour and its place within the public sphere. He completed his PhD in 2014 at the University of Amsterdam, as part of the research project The Power of Satire: Cultural Boundaries Contested, funded by the Netherlands Organisation for Scientific Research (NWO), and led by Marijke Meijer Drees and Sonja de Leeuw. His dissertation discussed the intermedial and intercultural dimensions of satire during the Dutch Age of Revolution (1780-1800). He has published widely in both national and international academic journals on humour, satire, and related topics. More recently, he also started working as a comedy critic for the Dutch online review platform Theaterkrant.nl.

47 Piet Bakker, 'Jongeren nemen afscheid van traditionele tv,' Stimuleringsfonds voor de Journalistiek.

48 'Zondag met Lubach,' Ster. 